\title{
The Helping Behavior of Senior and Vocational High School Students Based on the Values of Pancasila in Pemalang Regency
}

\author{
Dedit Priyono, Alvanov Z Mansoor, Intan R Mutiaz \\ Faculty of Art and Design (FSRD), Institut Teknologi Bandung (ITB) \\ Bandung, Indonesia \\ Belozoglu.dt@gmail.com, nova.zp@gmail.com,intanrm@yahoo.com
}

\begin{abstract}
The decline in a social relationship has led people, particularly teenagers, to an unwillingness to help others. Therefore, there needs such an effort to help teenagers realize the importance of helping others. One possible effort is to hold a character building program. In this case, the writer involves Pancasila as the fundamental principle of the program to relate its values to the helping behavior the teenagers might show. Accordingly, this study focuses on finding the helping behavior related to the values contained in the Sila of Pancasila shown by the teenagers. This descriptive-qualitative study uses Focus Group Discussion (FGD) and literature study methods to collect data. From the research, the writer finds Sila 2 Kemanusiaan Yang Adil dan Beradab fits the helping behavior shown by the teenagers the most. The helping behavior shown relates, particularly, with the following values of Pancasila, i.e., "To recognize equality both in rights and responsibility, to uphold the values of humanity," and "To promote fairness to others." Nevertheless, teenagers have not shown yet the one related with "To practice tolerance and show empathy."
\end{abstract}

Keywords: Focus Group Discussion (FGD), Pancasila, Teenagers, Helping Behavior.

\section{INTRODUCTION}

The culture of helping others has been part of Indonesian people. The habit of helping others has been implemented by Indonesian people from one generation to another one. In line with Ibnu Khaldun in Saragih (2015) that living together and helping each is considered human core need. This need has to be fulfilled so as to keep humanity exists. To make it happen, collectivismshould be involved for the sake of forming social order in which people cannot live alone. Accordingly, people live together in a mutual relationship where they can share each other to fulfill their need of life.

The helping behavior is a crucial thing as people are social beings in nature. They will never be able to live alone. People need others since they were born. This is in line with Sears in Gigy (2014) who clarified that "people are not individual beings who can live alone, yet social beings who really need others." The helping behavior means the willingness to help others sincerely. In other words, according to Santrock in Waas (2015), "helping behavior is prioritizing other who need help rather than prioritizing personal interests." Helping behavior should have been owned by human, and it needs to be taught to humans since they were kids.

Puberty, as Hurlockin Herlina (2016) stated, is subdivided into two, i.e., immature(11/12-16/17years old) and mature(16/17-18years old).Individually, teenagers reach their maturity during their late adolescence. Krori in Herlina (2016) added that teenage is a crucial period of life, which covers the period of transition, the period of change, the period of which teenagers are in the age of trouble, the period in which teenagers search for their self-identities, the period of dreadness, the period of unrealism, and the period of threshold towards maturity.

Nowadays, the interaction among people has shifted as a result of the era of globalization and modernization. It is followed by the change of the values of social life both quantitatively and qualitatively. People tend to be selfish. The decline of willingness to help others indicates this kind of phenomenon. It happens within societies, especially teenagers. The helping behavior among teenagers starts to be decreasing. It significantly increases the individualism among teenagers. Besides, the teenagers' lifestyle, which is hedonistic, causes the teenagers to be egoistic and ignorant towards the condition of others. They have been individualistic ones and tend to be aggressive by showing off violence and others juvenile crimes.

The fact that teenagers tend to be aggressive can be known from the news reported by media like television and newspaper. For instance, there had ever been news about the death of supporters in a football match between PERSIB versus PERSIJA. As cited in Kompas online, the case happened for one of the PERSIB supporters was seriously injured after being attacked by the supporters of PERSIJA. The injury caused the supporter of PERSIB to die. The detailed chronology can be accessed in(http://regional.kompas.com/read/2017/07/28/07535911 /kronologi-pengeroyokan-ricko-bobotoh-persib-yangmeninggal-dunia). Besides, the video of the case was widely spread. 
Another news about the juvenile crime was the fight among female teenagers uploaded via youtube by weka animal lovers (2016), a youtuber account, named "cewek Bandung berkelahi sampe buka bukaan." The video was watched by more than one million viewers. Ironically, the fight was watched and even recorded by their peers.

Those two examples draw a conclusion that it is a necessity to build the teenagers' character based on a strong principle. It is considered so in order to guide teenagers to behave properly in their social lives. With regard to that idea, Pancasila, as the ideology of the country, is then considered right as the basic principle in building the characters of teenagers. It is because Pancasila has values, which are in line with the effort of building the characters of teenagers in that nationalism based characters is set as the goal. The values are included in each sila of Pancasila. The values of Pancasila are deemed as norms regulating how people live their lives.

According to Moedjantoin Wahana (1993), the values of Pancasila has the lure that attracts peopleto carry them out. He stated also that the values are considered as a goal, which motivates the Indonesian citizen to behave and do something. The importance of the values of Pancasila had been formulated by the founders of Indonesia.The formulation was based on the consideration that the values of Pancasila are in line with the ideal way of life of Indonesia.Therefore, as the Indonesian citizen, we must uphold them in our lives.

Based on the brief explanation above, the aims of the research are as follows: (i) to define the helping behavior shown by teenagers in Pemalang Regency, (ii) to find out the forms of the helping behavior known by teenagers according to the values of Pancasila.

\section{Method}

This descriptive-qualitative research used Focus Grup Discussion (FGD) and the study of literature. Focus Group Discussion (FGD) was done twice. The first one was done at the terrace of the mosque of SMK PGRI 2 Taman with the ten school activists. It aimed to find the teen communities in Pemalang Regency.

The second Focus Group Discussion (FGD) was done at the same place with different participants. There were eight representatives of the teen communities, such as: motor club, urbex people, skateboard freestyler, Pecinta Goyang Dangdut Koplo (PGDK), Bis Komunity, Muppets (Komunitas Pecinta Pets Pemalang), Syechermania, and Pecinta Grup Al-munsidin. The discussion was aimed to find out the forms of the helping behavior the teenagers know.

The discussion and interview on the helping behavior among teenagers were done to find out the helping behavior related to the values of Pancasila. The values of Pancasila addressed are the ones taken from the book of UUD 1945 Amendment I,II,III, and IV, which is published by the team of Palito Media (2016). The values addressed are those reflecting the helping behavior.

Focus Group Discussion (FGD) was done to find out the teenage communities in Pemalang regency and the helping behavior known by the teenagers. The literature study was used to find out the helping behavior available in the values of Pancasila.

In the Sila Ketuhanan Yang Maha Esa, there are 2 out of 7 values, which address the helping behavior i.e., 1) To develop tolerance towards the practice of worship according to the individual belief, and 2) Not to impose others on the individual belief.

In the Sila Kemanusiaan yang adil dan beradab, there are 6 out of 10 values, which address the helping behavior, i.e.: 1) To recognize the equality in self-dignity and human rights regardless of the tribes, ancestry, religion, beliefs, sex, social status, skin color, etc., 2) To develop the loving behaviour towards others, 3) To develop tolerance and respect towards others, 4) To remind people of the arbitrariness they need to get rid off, and 6) To encorage people to stand on the truth and justice.

Meanwhile, there is no value addressing the helping behaviour found in the Sila Persatuan Indonesia dan Kerakyatan yang dipimpin oleh hikmat kebijaksanaan dalam permusyawaratan perwakilan.

In the SilaKeadilan sosial bagi seluruh rakyat Indonesia, there are 4 out of 11 values, which address the helping behaviour i.e.: 1) To encourage people to do good things, which reflect togetherness and mutual help, 4) To respect human rights, 5) To encourage the practice of helping others, and 11) To encourage the practice of doing good things for the sake of betterment in life.

\section{FINDINGS AND DISCUSSION}

\section{III.1. The teenage communities of the Senior and Vocational High Schools in Pemalang regency.}

The pre-adolescent development, as Sulaeman (1995) stated, is marked by the increase of interests in personal appearance. Besides, the formation of the peer group and the social activities that follow indicate it so. The preadolescent development is also affected by the previous development, which contributes towards the ability the teenagers may have to communicate and socialize with others. It is in line with Conradi in Sulaeman (1995) who believed that teenagers are able to participate well in social life when they have undergone the pre-adolescent development proportionally.

In the adolescence period, teenagers are interested more in involving themselves in the teenage groups or communities. It is considered as a common part the teenagers normally undergo. In this case, the communities the teenagers involve themselves in are the ones that address their certain orientation, norms, and values, and the deal they set and is agreed by their group.Next, it is also explained about the group or crowd made by some certain teenagers in that their presence is not only based on the same interests among them, but also on the same need and motivation to do various social activities.

To make it easier, I classified the teenage communities based on the sameness of behavior or hobbies among them. The communities were then specified according to each category of the communities. It was aimed to involve the members of teenage 
communities who represent their communities. The categories of the teenage communities in Pemalang regency can be seen on table I.

Tabel I.The categories of teenage communities and their representation in Pemalang Regency

No Categories Representation

\begin{tabular}{|c|c|c|}
\hline 1 & Remaja Touring & $\begin{array}{l}\text { One Look Style (OLS) Zone } \\
\text { Pemalang }\end{array}$ \\
\hline 2 & $\begin{array}{l}\text { Remaja Alim } \\
\text { (Rajin Ibadah) }\end{array}$ & Syechermania Pemalang \\
\hline 3 & $\begin{array}{l}\text { Remaja Musik } \\
\text { (Band) }\end{array}$ & Al-Munsyiders Pemalang \\
\hline 4 & Remaja Kekinian & Urbex People \\
\hline 5 & Remaja Sporty & $\begin{array}{l}\text { Freestyler Skateboard } \\
\text { Pemalang }\end{array}$ \\
\hline 6 & $\begin{array}{l}\text { Remaja } \\
\text { Entertainment }\end{array}$ & $\begin{array}{l}\text { Pecinta Goyang Dangdut } \\
\text { Koplo }(P G D K)\end{array}$ \\
\hline 7 & Remaja Hobi Unik & BisComunity Pemalang \\
\hline 8 & $\begin{array}{l}\text { Remaja Pencinta } \\
\text { Binatang }\end{array}$ & $\begin{array}{l}\text { Komunitas Pecinta Pets } \\
\text { Pemalang (Muppeng) }\end{array}$ \\
\hline
\end{tabular}

The representation of each teenage community has its own characteristic, which is diverse from other teenage communities. Each of the teenage communities has similar attribute used when they meet their members.

\section{III.1.1. Remaja Touring}

Remaja touring is the category of the teenage community represented by One Look Style (OLS) Zone Pemalang. It is one of the teenage communities whose interest is in automotive, particularly motorcycle. They usually meet their members around Taman, an area in Pemalang, every weekend to have touring activity. Besides, they occasionally do a social activity like sharing with needy people through the fund they raise among them or others. Another activity they frequently do is a set of introduction to their community to recruit new members. Commonly, they have their own identity and serial numbers they stick on their motorcycles and certain attributes they wear to mark their communities. For the sake of further information about the communities, I provide the following table and figure.

Tabel II. Information aboutOne Look Style (OLS) Zone Pemalang

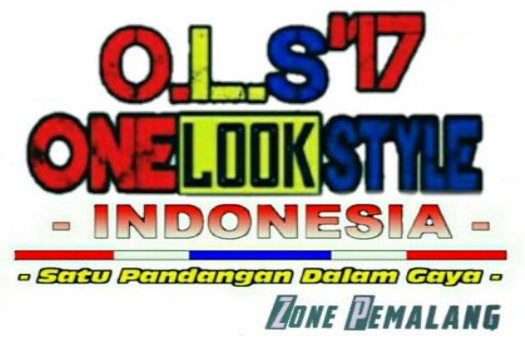

Figure1. The logo of One Look Style (OLS)

\section{ZonePemalang community \\ (Photo Credit: The member of community)}

\begin{tabular}{|c|c|}
\hline $\begin{array}{l}\text { The number of the } \\
\text { members }\end{array}$ & 28 Persons \\
\hline Assembly Point & $\begin{array}{l}\text { J1. WahidinSudirohusodo, Ds. } \\
\text { KaligelangKec. Taman }\end{array}$ \\
\hline Attribute & Sticker, Member Card \\
\hline Routines & Touring and Gathering \\
\hline
\end{tabular}

Figure2.Documentation of the One Look Style (OLS) Zone Pemalang Community (Photo Credit: The Member of Community)
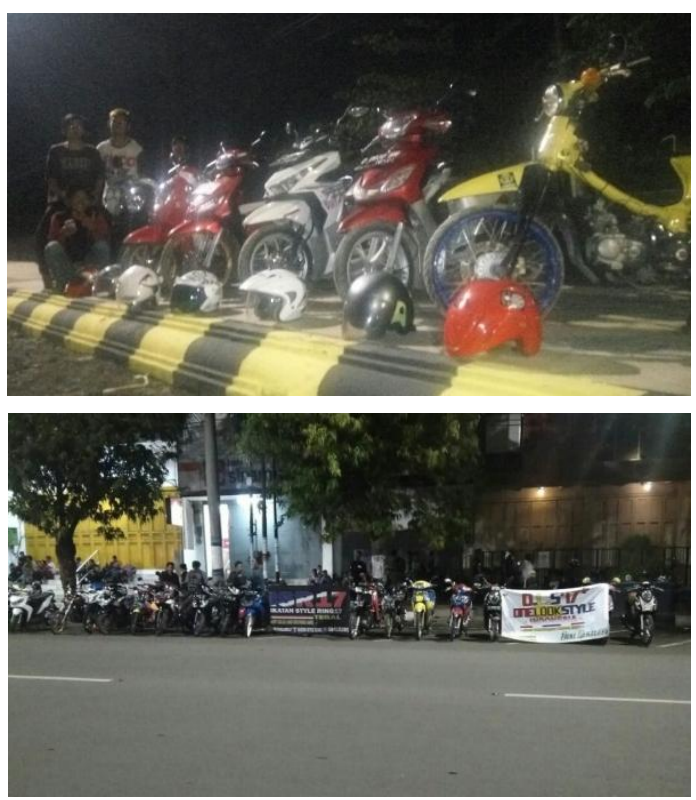

\section{III.1.2. Remaja Alim (Rajin Ibadah)}

Remaja Alim is the category of the teenage community represented by SyechermaniaPemalang. The focus of the community is on the religious activities. The formation of the community is based on their adoration of a Habib Syech from Pekalongan. Syechermaniais one of the popular communities whose members are mostly the teenagers living in the coastal area along the northern Java Sea. Attending the da'wah from the Habib Syech is the activities done by the communities. They regularly come to the house of Habib Syech or places the Habib Syech does his da'wah to attend the da'wah. They listen the da'wah and following the shalawat recited by the Habib Syech. Another activity they do is having a discussion on the agenda of the next da'wah and holding a regular meeting among the members to have tahlilan (a religious activity done through reciting Qur'an and prayer). For further information about the community, I provide the following table and figure. 
Table III.Information aboutSyechermania Pemalang

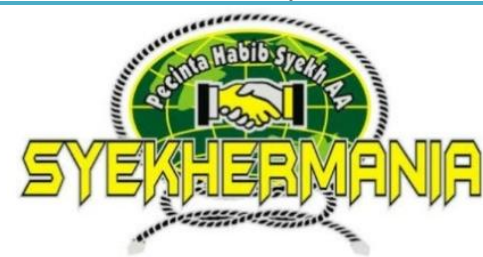

Figure3.The Logo of

SyechermaniaPemalangCommunity

(Photo Credit: The Member of Community)

\begin{tabular}{|c|c|}
\hline $\begin{array}{l}\text { The number of } \\
\text { the member }\end{array}$ & 45 Persons \\
\hline Assembly Point & $\begin{array}{l}\text { In the house of the member who } \\
\text { gets the turn for tahlilan }\end{array}$ \\
\hline Attributes & $\begin{array}{l}\text { Sticker, A Specific Blazer with a } \\
\text { Logo of Community and Name } \\
\text { Tag }\end{array}$ \\
\hline Routines & $\begin{array}{l}\text { Attending the da'wah by the Habib } \\
\text { Syech }\end{array}$ \\
\hline
\end{tabular}

Figure4.The Document of Syechermania Pemalang Community Attending the Da'wah by theHabibSyech

(Photo Credit: The Member of the Community)

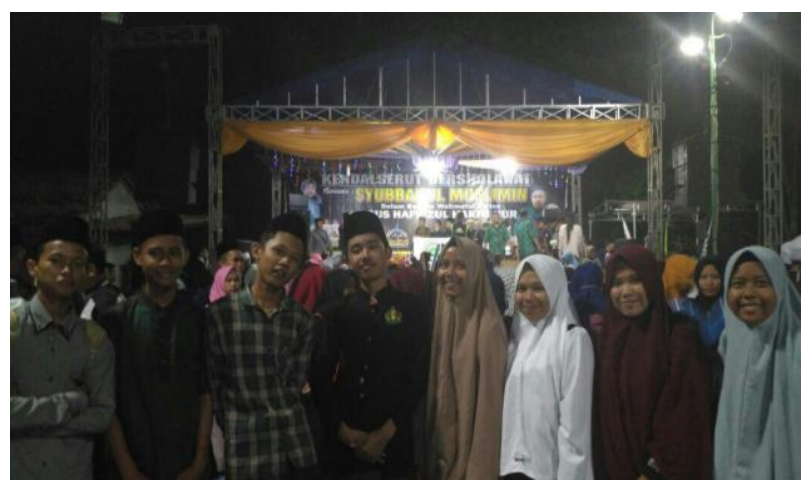

III.1.3. Remaja Musik (Band)

Remaja Musik (Band) is the community category represented by Al-MunsyiderPemalang community. It is one of the teenage communities whose members love doing shalawat followed by a certain kind of music called hardroh or rebana. The formation of a community is based on the adoration of a religious band in which hadroh or rebana is played. It is Al-Munsyidin the band they adore, which comes from Pekalongan. The band invites its fans to have shalawat followed by its own musical arrangement. Remaja Musik (Band) community regularly attend the shalawat performed by the band every Sunday. They also join the band practicing playing the hadroh or rebana. For further information about the community, I provide tables and figure below.
Table IV. Information about the Al-MunsyiderPemalang Community

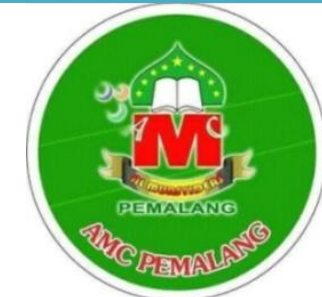

Figure5.The Logo of Al-MunsyiderPemalang Community

(Photo Credit: The Member of Community)

\begin{tabular}{ll}
$\begin{array}{l}\text { The number of } \\
\text { the member }\end{array}$ & $\begin{array}{l}\text { 45 Persons } \\
\text { Assembly }\end{array}$ \\
$\begin{array}{l}\text { Point } \\
\text { gets the house of the member who }\end{array}$ \\
Attributes & $\begin{array}{l}\text { Sticker, specific blazerwith the logo } \\
\text { of community and name tag }\end{array}$ \\
Routines & $\begin{array}{l}\text { Attending the concert and shalawat } \\
\text { performed by Al-Munsyidin }\end{array}$ \\
\hline
\end{tabular}

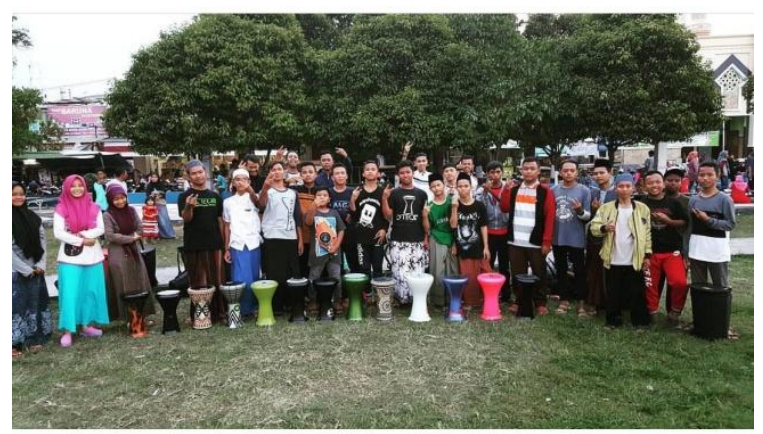

Figure6.The Documentation of $\mathrm{Al}$ -

MunsyiderPemalangCommunity Having Their Regular Activity

(Photo Credit: The Member of the Community)

\section{III.1.4. Remaja Kekinian}

Remaja Kekinian (nowadays teenagers)is the community category represented by Urbex People community. The community is formed by those who are interested in fashion and willing to always look stylish and fashionable. They reflect themselves by wearing the up-to-date clothes and taking a selfie with an extreme background. They wear masks as their attribute when taking the selfie. They usually hunt unique places like old buildings, bridges, railway, and new places to take the selfie. Afterward, they upload the photos to their Instagram account. For further detail about the community, I provide table and figure as follows. 
TableV. Information aboutUrbex People

\section{U R B E X PEOPLE}

P E MA L A NG

Figure7.The Logo of Urbex PeoplePemalang Community

(Photo Credit: The Member of the Community).

\begin{tabular}{ll}
\hline $\begin{array}{l}\text { The number of } \\
\text { members }\end{array}$ & 18 Persons \\
\hline Assembly points & Some cafes in Pemalang \\
\hline Attributes & $\begin{array}{l}\text { Masks, Cameras (HP/DSLR), and } \\
\text { up-to-date clothes/outfits }\end{array}$ \\
Routines & $\begin{array}{l}\text { Taking the selfie with unique } \\
\text { places as the background }\end{array}$ \\
\hline
\end{tabular}

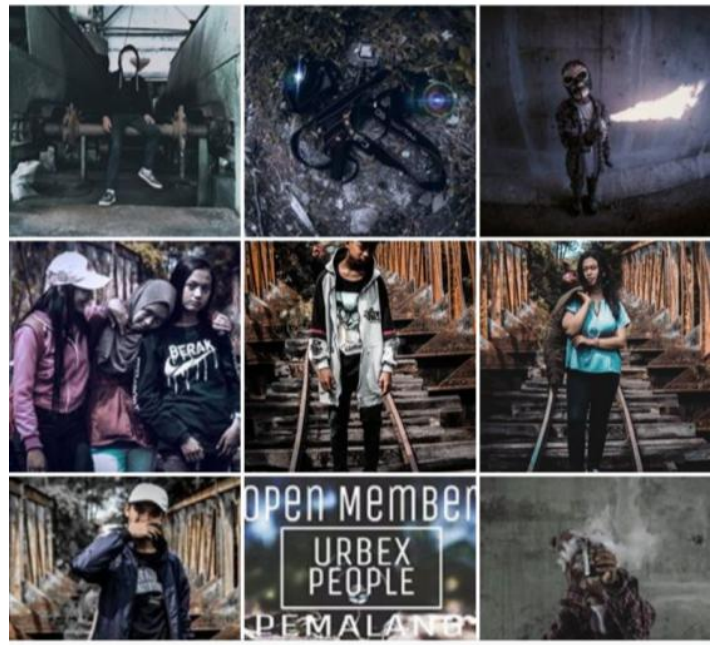

Figure8.The Photos of Urbex PeoplePemalang

Community

(Photo Credit: Instagram)

\section{III.1.5. Remaja Sporty}

Remaja Sporty is the category of the community represented by Freestyler Skateboard Pemalang. The members of Remaja Sporty are those who like doing physical exercise, especially freestyle skateboard. The community is divided into two according to the areas. The areas cover the southern and northern Pemalang regency. They regularly practice the techniques of skateboarding. Besides, they often take part in some freestyle events, both regional and national. For the detail, I provide the tables and figure as follow.
Table VI. Information about Freestyler Skateboard Community

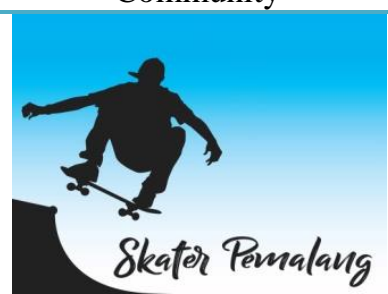

Figure9.The Logo of Freestyler

SkateboardPemalang Community

(Photo Credit: The Member of the Community)

\begin{tabular}{|c|c|}
\hline $\begin{array}{l}\text { The number of } \\
\text { members }\end{array}$ & 13 Persons \\
\hline Assembly Point & $\begin{array}{l}\text { Around the Pendopo of Pemalang } \\
\text { regency and SMKN Randudongkal }\end{array}$ \\
\hline Attribute & Skateboard \\
\hline Routines & $\begin{array}{l}\text { Practicing the techniques of } \\
\text { freestyle skateboard }\end{array}$ \\
\hline
\end{tabular}
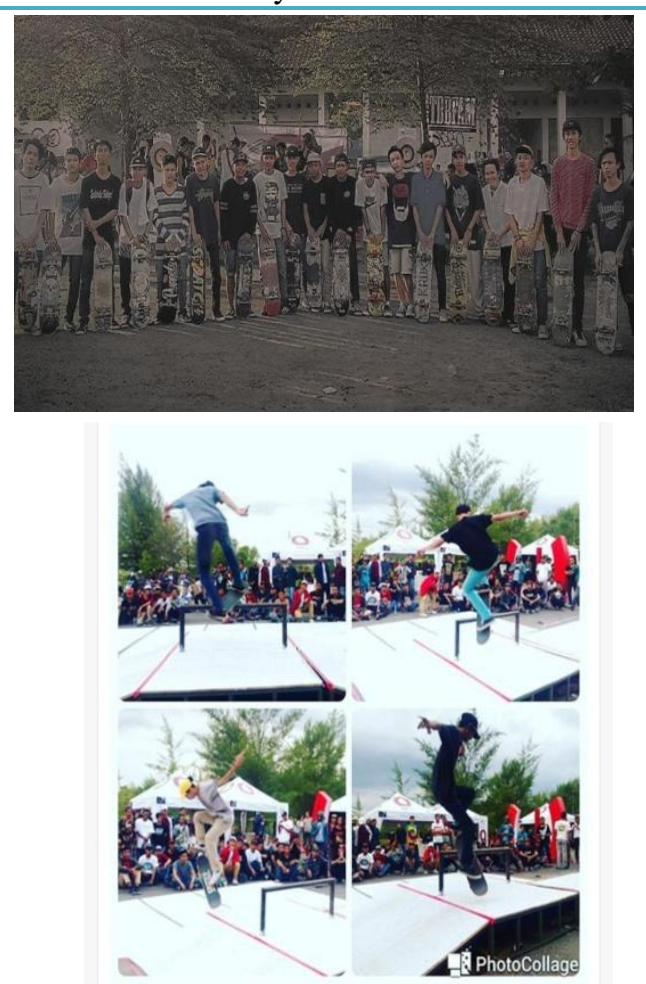

Figure1. The Documentation of Freestyler SkateboardPemalang Community Practising the Techniques of Freestyle Skateboard

(Photo Credit: The member of the community)

III.1.6. Remaja Entertainment

Remaja Entertainment is the category of the community represented by PasukanGoyangDangdutKoplo (PGDK) Pemalang community. The formation of the community is based on its members' interest in goyang (i.e., dancing) dangdut koplo (popular music genre in Indonesia). The community is present in every coastal area along the northern Java Sea called Pantura. The members of the community usually hunt the dangdut music concerts 
around Pemalang, Tegal, Brebes, and Pekalongan. In the dangdut concert they attend, they dance in unique waysand following the beat. Their routine agenda is discussing the dangdut concerts, which may be held in every week and practicing dancing or goyang dangdut. For the detail, I enclose the following tables and figures.

TableVII.Information

aboutPasukanGoyangDangdutKoplo (PGDK) Pemalang

\begin{tabular}{|c|c|}
\hline \multicolumn{2}{|c|}{$\begin{array}{c}\text { Figure11. The Logo of } \\
\text { PasukanGoyangDangdutKoplo (PGDK) Pemalang } \\
\text { (Source: the member of the community) }\end{array}$} \\
\hline $\begin{array}{l}\text { The number of } \\
\text { members }\end{array}$ & 54 Persons \\
\hline Assembly Point & Pemalangtown square \\
\hline Attribute & Outfit \\
\hline Routine & $\begin{array}{l}\text { Hunting the dangdut concerts and } \\
\text { practicing dancing or goyang } \\
\text { dangdut }\end{array}$ \\
\hline
\end{tabular}

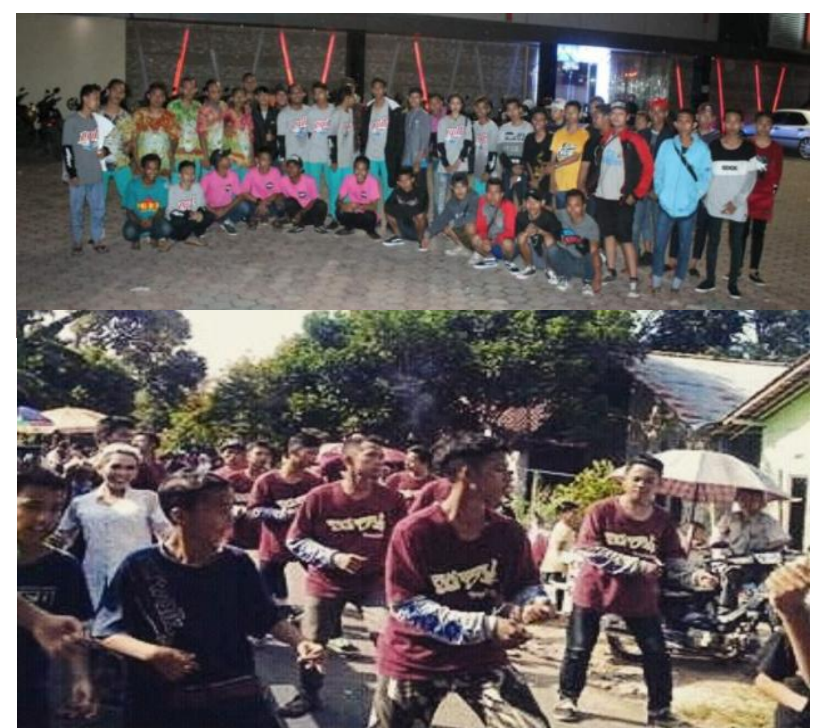

Figure12. The Documentation of PGDK Pemalang Activity

(Photo credit: the member of community)

\section{III.1.7. Remaja Hobi Unik}

Remaja Hobi Unik (i.e., The Teenage Unique Hobbies) is the category of the community represented by the Bismaniacommunity. The community is formed based on the enthusiasm for buses in Indonesia. Pemalangis one of the largest one among the communities. It presents in almost all cities in Indonesia. The activities done by the community are such as hunting some newly issued buses and capturing the buses running on the highway. Besides, they upload the pictures of the buses to their social media accounts. They also campaign to encourage people to use public transportation, especially buses, instead of their own vehicles. They do it so for the sake of reducing the air pollution. The detail about the community can be seen in the following table and figure.

TableVIII.Information about the BismaniaPemalang Community

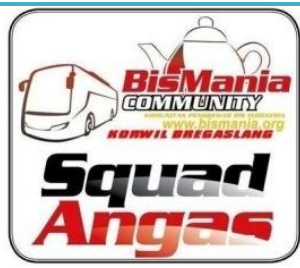

Figure13.The Logo of BismaniaPemalang

Community

(Source: the member of the community)

\begin{tabular}{|c|c|}
\hline $\begin{array}{l}\text { The number of } \\
\text { members }\end{array}$ & 45 Persons \\
\hline Assembly Point & $\begin{array}{l}\text { Pemalang town squares and the } \\
\text { house of each member }\end{array}$ \\
\hline Attribute & Outfit \\
\hline Routines & $\begin{array}{l}\text { Hunting and capturing buses, } \\
\text { touring with the bus, and sharing } \\
\text { information about buses (e.g., the } \\
\text { bus facilities, etc.) }\end{array}$ \\
\hline
\end{tabular}

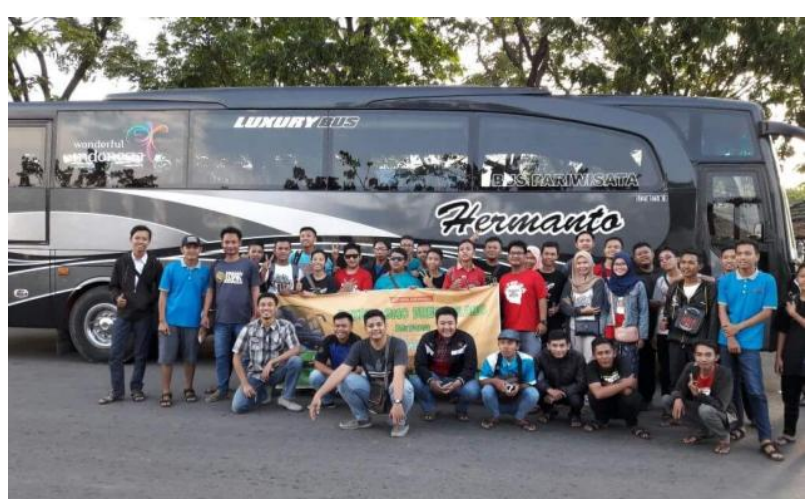

Figure14. The Documentation of BismaniaPemalang Activity

(Source: the member of the community)

\section{III.1.8. Remaja Pecinta Binatang}

Remaja Pecinta Binatang (i.e., pet lovers) is the category of the community represented by Badut Cobra Talenta (Barata). This community has its regular activity, that is, showing public various reptiles, especially snakes. They show public how to control poisonous snakes. Besides, they campaign to persuade people to love and take care of reptiles and to handlethe injury caused by the reptile's bite in a right way. For the detail about the community, I enclose table and figure as follow.

Table IX. Information aboutBadut Cobra Talenta (Barata) Pemalang. 


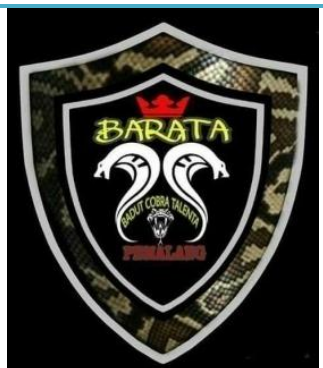

Figure2. The Logo of Badut Cobra Talenta (Barata) Pemalang Community

(Source: the member of the community)

\begin{tabular}{|c|c|}
\hline $\begin{array}{l}\text { The number } \\
\text { of members }\end{array}$ & 17 Persons \\
\hline $\begin{array}{l}\text { Assembly } \\
\text { point }\end{array}$ & $\begin{array}{l}\text { Pemalang town squares, Patih } \\
\text { Sampun Park, and other bustling } \\
\text { places around Pemalang }\end{array}$ \\
\hline Attribute & Outfit and reptiles \\
\hline Routine & $\begin{array}{l}\text { Training the agility of reptiles and } \\
\text { Socializing the snake bite first aid kit }\end{array}$ \\
\hline
\end{tabular}

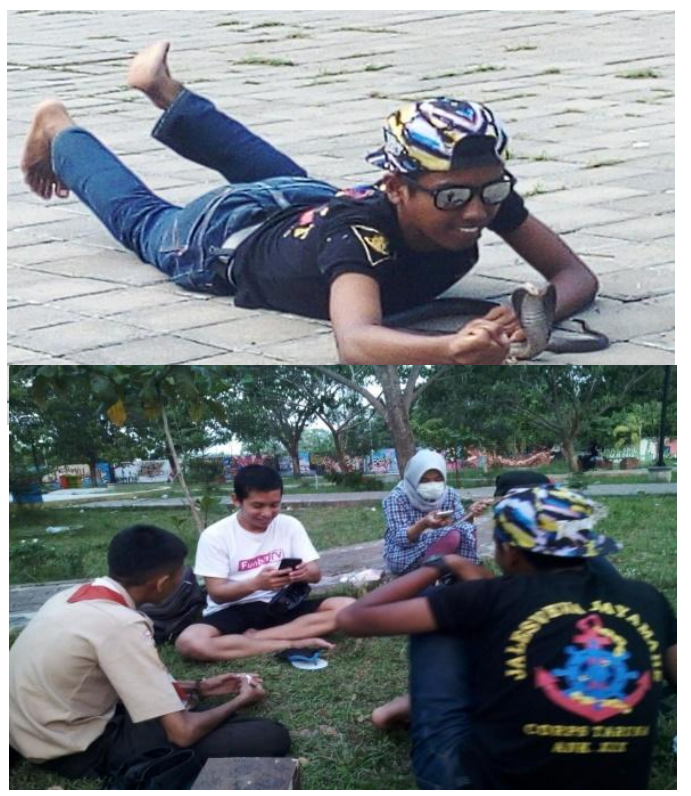

Figure 3. The Activity of Badut Cobra Talenta (Barata) PemalangCommunity

(Source: the member of the community).

III.2. The Helping Behavior Based On the Values of Pancasila

The data of the helping behavior based on the values of Pancasila was found out from the discussion with one representative from each of the teenage communities in Pemalang regency. The discussion and interview were addressed to the eight students of the Vocational School of PGRI 2, Taman. Those eight students were from One Look Style (OLS) Zone Pemalang, urbex people, skateboard freestyler, Pasukan Goyang Dangdut Koplo (PGDK), BisMania, Badut Cobra Talenta (Barata), Syechermania, and Al-Munsyider.

The discussion consisted of three main sections: asking students' opinion about helping each other, asking students' opinion about solidarity and the reasons why we need to help others, and asking students about the helping behavior according to the values of Pancasila.

In the first section of the discussion, the students representing each of their community agreed that helping behavior is an effort to help others overcome the problemsand face the difficulties they may have. Next, in the second section of the discussion, the students were interviewed. The questions asked was about solidarity and why they need to help others. From the opinion they shared, there were four reasons why they need to help others: 1) empathy, 2) the nature of humans as social beings, 3) religious orders and culture, and 4) sympathy. The last section of the discussion, the participants were asked about the helping behavior related to the values of Pancasila. It was found that only some values of Pancasila addressing the helping behavior. The values were further discussed and the result of the discussion

\section{III.2.1. SilaPertama "Ketuhanan Yang MahaEsa"}

Regarding the value " To develop tolerance towards the practice of worship according to the individual belief," the representative of the Pecinta Sholawat and Klub Motorsaid that they have ever lent their friends who would pray or salat. As well as the representative from Pecinta Reptil community, they even set their friends free to pray or salat.

Their behavior can be related to the value of SilaKedua Pancasila "Kemanusiaan Yang Adil Dan Beradab": To develop tolerance among others. For further detail about the helping behavior related to Sila Pertama Pancasila, I provided the following table.

TabelX. Bentuk Perilaku Menolong Dari Sila Ke-1

\begin{tabular}{|c|l|ll|}
\hline \multicolumn{2}{|c|}{ SILA Ke-1: "Ketuhanan Yang Maha Esa" } \\
\hline 1 & $\begin{array}{l}\text { To develop tolerance } \\
\text { towards the practice } \\
\text { of worship according } \\
\text { to the individual } \\
\text { belief }\end{array}$ & $\begin{array}{l}\text { Lending their friends } \\
\text { sarongs for praying } \\
\text { or salat }\end{array}$ \\
$\begin{array}{l}\text { 2. } \\
\text { Allowing their } \\
\text { friends to pray or } \\
\text { salat }\end{array}$ \\
\hline
\end{tabular}

\section{III.2.2. SilaKedua "Kemanusiaan Yang AdildanBeradab"}

Next, the helping behaviour related to the values included in the Sila Kedua Pancasila i.e., "Kemanusiaan Yang Adil dan Beradab", are"To recognize the equality in self-dignity and human rights regardless of the tribes, ancestry, religion, beliefs, sex, social status, skin color, etc." and " To remind people of the arbitrariness towards others they need to get rid off". In line with those values, the PGDK community has ever helped their classmate who had ever been bullied by his friends. As well as the Bus dan Pecinta Reptil communities, they both have ever done the same things as the PGDK community did. Even more, the Skateboard community, they also have ever helped their poor neighbor who was demeaned by another neighbor. The father of one of the community members also tried helping by advising the person demeaning his neighbor.

Another helping behavior was the one related to the value of Sila Kedua Pancasila "Kemanusiaan Yang Adil 
dan Beradab": To uphold the values of humanity. The practice of the value was shown by Komunitas Motor who helped an elderly to cross the road. They also helped an old farmer bringing a sack of grain which fell from his bicycle. They helped the farmer collecting the grain and put it back into the sack. Meanwhile, the Skateboard community has also ever helped a person who got accident by moving the victim aside the road. Similarly, the Komunitas Bis allowed a woman to seat on their bus seats. Besides, the PGDK community has ever tried reconciling two persons who fought in a small concert (Orkes Kampung).

Another helping behavior related to the value "To love doing the action of humanism" of Sila Kedua Pancasila was shown by Komunitas Motor who raised fund for helping the victims of natural disaster in Subang and Sumedang, West Java. Komunitas Pecinta Reptilalso shared their experience of helping others. They have ever joined a community service to renovate their poor neighbor. For the detail, I enclosed the following table.

TabelXI.The helping behavior related to Sila Kedua

SILA Ke-2: "Kemanusiaan Yang Adil dan Beradab"

\begin{tabular}{|c|c|c|}
\hline 1 & To develop tolerance & $\begin{array}{l}\text { 1. Lending friends } \\
\text { sarongs for praying }\end{array}$ \\
\hline 2 & $\begin{array}{l}\text { To recognize the } \\
\text { equality in self-dignity } \\
\text { and human rights } \\
\text { regardless of the tribes, } \\
\text { ancestry, religion, } \\
\text { beliefs, sex, social } \\
\text { status, skin color, etc. }\end{array}$ & $\begin{array}{l}\text { 1. Helping a friend who } \\
\text { was being bullied } \\
\text { 2. Helping a neighbor } \\
\text { demeaned by other }\end{array}$ \\
\hline 3 & $\begin{array}{l}\text { To remind people of } \\
\text { the arbitrariness } \\
\text { towards others, they } \\
\text { need to get rid off }\end{array}$ & $\begin{array}{l}\text { 1. Melakukan } \\
\text { pembelaan terhadap } \\
\text { teman yang dibully } \\
\text { 2. Membela tetangga } \\
\text { yang sedang dihina }\end{array}$ \\
\hline 4 & $\begin{array}{l}\text { To uphold the value of } \\
\text { humanity }\end{array}$ & $\begin{array}{l}\text { 1. Helping an elderly } \\
\text { crossing the road } \\
\text { 2. Helping a farmer } \\
\text { falling from his } \\
\text { bicycle } \\
\text { 3. Helping a victim of } \\
\text { an accident } \\
\text { 4. Allowing a woman } \\
\text { to seat on their bus } \\
\text { seats } \\
\text { 5econciling two } \\
\text { persons fighting in a } \\
\text { small concert (orkes } \\
\text { kampung) }\end{array}$ \\
\hline 5 & $\begin{array}{l}\text { To love doing the } \\
\text { action of humanism }\end{array}$ & $\begin{array}{l}\text { 1. Raising fund for } \\
\text { helping the victims } \\
\text { of natural disaster in } \\
\text { Subang and } \\
\text { Sumedang, West } \\
\text { Java } \\
\text { 2. Joining a community } \\
\text { service to help to } \\
\text { renovate their }\end{array}$ \\
\hline
\end{tabular}

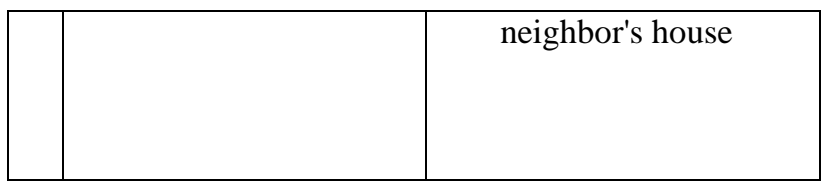

\section{III.2.3. SilaKelima "KeadilanSosialBagiSeluruh Rakyat Indonesia"}

The helping behavior related to the value "To respect the right of others" fo Sila Kelima Pancasila was found through discussion. The participants of the discussion were first given an explanation about the helping behavior related to the value aforementioned. The participants were asked to give their opinions about motorists who disobeyed the traffic rules such as stopping at zebra crossing when the traffic light was red and those who passed their vehicles through pavement when traffic jam.

All participants of the discussion gave the same opinions towards the issue. They thought that the disobedience has done by the motorists obviously deprived the right of others. They said that the motorists should not have done those traffic violations for the sake of allowing the pedestrians to cross easily. They also said that passing the vehicles through the pavements disturbed the pedestrian to walk comfortably. The participants further said that they saw those traffic violations through the TV. They added that they never saw those traffic violations directly around them. They thought that Pemalang is unlike other big cities where the traffic is always jam. For the detail, I enclosed the following table.

TableXII.The Helping Behaviour Related to Sila Ke-5

\begin{tabular}{|c|c|c|}
\hline \multicolumn{3}{|c|}{$\begin{array}{l}\text { SILA Ke-5: "Keadilan Sosial Bagi Seluruh Rakyat } \\
\text { Indonesia" }\end{array}$} \\
\hline 1 & $\begin{array}{l}\text { Respecting } \\
\text { the right of } \\
\text { others }\end{array}$ & $\begin{array}{l}\text { 1. Driving orderly (by always } \\
\text { obeying the traffic rules) and } \\
\text { respecting the right of others }\end{array}$ \\
\hline
\end{tabular}

\section{CONCLUSION}

From the discussion aforementioned, it can be concluded that most of the participants have known and are able to explain about the helping behavior related to the values of Pancasila. The values of Pancasila addressing the helping behaviour the participants of the discussion have known cover "To develop tolerance towards the practice of worship according to the individual belief" (in Sila Pertama Pancasila), and "To recognize the equality in self-dignity and human rights regardless of the tribes, ancestry, religion, beliefs, sex, social status, skin color, etc." and " To remind people of the arbitrariness towards others they need to get rid off" (in Sila Kedua Pancasila).

Meanwhile, the value of Pancasila (in Sila Kedua), the participants, could not describe was the value "To develop tolerance among others." The participants only mentioned the examples towards tolerance, i.e., lending their friends sarongs for praying and suggesting motorists to obey the traffic rules. 


\section{REFERENCES}

Lover, W.A. (2016) cewek bandung berkelahi sampe buka bukaan, Data diperoleh Pada tanggal 4 Agustus 2017, melalui situs internet : https://www.youtube.com/watch?v=vtffVT44XrQ\&ha s_verified $=1$,

Dayaksini, T., \& H (2009) Psikologi Sosial. Malang, Indonesia : Universitas Muhammadiyah Malang Press.

Djawa Gigy, N.M. (2014) Studi Deskriptif Mengenai Motivasi Tolong menolong Pada Mahasiswa Profesi Dokter (Koasisten) Universitas " $\mathrm{X}$ " Bandung.

Herlina (2013) Bibliotherapy: Mengatasi Masalah Anak dan Remaja Melalui Buku. Bandung: Pustaka Cendekia Utama.

Buku Didownload pada tanggal 5 Agustus 2017 dari situs http://file.upi.edu/browse.php?dir=Direktori/FIP/JUR. PSIKOLOGI/196605162000122-HERLINA/

Pemerintah Republik Indonesia (Editor Tim Palito Media) (2016) Undang-Undang Dasar (UUD) Republik Indonesia 1945 Amandemen I,II,III,IV. Jakarta, Indonesia : Palito Media

Ramdhani, D (Ed.). (27 Juli 2017) Kronologi pengeroyokan ricko bobotoh persib yang meninggal dunia, Data diperoleh pada tanggal 4 Agustus 2017, melalui situs internet http://regional.kompas.com/read/2017/07/28/0753591 1/kronologi-pengeroyokan-ricko-bobotoh-persibyang-meninggal-dunia.

Saragih, J.S (2015) Tradisi "Margugu" sebagai Sistem Tolong Menolong Pada Masyarakat Desa Marubun Lokkung, Kecamatan Dolok Silau, Kabupaten Simalungun.

Waas, K R (2015) Perbedaan Perilaku Menolong Pada Siswa Kelas VI SD Di Sekolah Berbasis Agama Dengan Siswa Kelas VI SD Di Sekolah Tidak Berbasis Agama (Umum) Di Salatiga.

Wahana, P (1993) Filsafat Pancasila. Yogyakarta, Indonesia : Kanisius 